\title{
Effect of xylazine, detomidine, medetomidine and dexmedetomidine during laparoscopic SCNT embryo transfer on pregnancy rate and some physiological variables in goats
}

\section{Amir Saeed Samimi}

Shahid Bahonar University of Kerman

Seyed Morteza Aghamiri ( $\sim$ aghamirimorteza@uk.ac.ir)

Shahid Bahonar University of Kerman

Mehdi Hajian

Royan Institute for Biotechnology, ACECR

Amir Masoud Samimi

San Diego University for integrative Studies

Amin Oroumieh

Shahid Bahonar University of Kerman

\section{Research Article}

Keywords: Physiological variables, Pregnancy rate, SCNT embryo, Laparoscopy, Goats

Posted Date: October 25th, 2021

DOI: https://doi.org/10.21203/rs.3.rs-1010155/v1

License: (c) (i) This work is licensed under a Creative Commons Attribution 4.0 International License.

Read Full License 


\section{Abstract \\ Background}

The present study was conducted to determine if using $\mathrm{a}_{2}$-adrenergic agonists results in decreased stress levels (lower cortisol levels) in goats used for laparoscopic embryo [somatic cell nuclear transfer (SCNT)] transfer; and there is an effect on pregnancy rate when stress levels are lessened. Sixty healthy does aged $24 \pm 4$ months and weighing $30 \pm 3 \mathrm{~kg}$ were used in experimental, prospective, randomized and blinded study. In this study, embryos were created via the Somatic Cell Nuclear Transfer (SCNT) method. Animals were randomly assigned to five groups: control (normal saline); xylazine $\left(100 \mu \mathrm{g} \mathrm{kg}^{-1}\right)$; detomidine (50 $\mu \mathrm{g}$ $\left.\mathrm{kg}^{-1}\right)$; medetomidine $\left(20 \mu \mathrm{g} \mathrm{kg}^{-1}\right)$; and dexmedetomidine $\left(5 \mu \mathrm{g} \mathrm{kg}^{-1}\right)$. Embryo transfer (through laparoscopic technique) began at 15 minutes and continued till 45 minutes post-treatment. Heart rate $(H R)$, respiratory rate $(R R)$, rectal temperature $(R T)$, and ruminal motility were performed before (baseline) and after drug administration. Pregnancy detection was performed 38 days after embryo transfer.

\section{Results}

Compared to control, $\mathrm{HR}, \mathrm{RR}$ and ruminal motility were significantly lower in $\mathrm{a}_{2}$-adrenergic agonists groups at 5-90, 15-60, and 5-120 minutes, respectively. Serum cortisol values significantly increased from baseline in the control group 45 minutes after drug administration $(p=0.001)$. At T45 and T120, serum cortisol concentration was significantly lower in $\mathrm{a}_{2}$-adrenergic agonists groups compared with the control. The pregnancy rate in control group $(n=4 / 12,33.3 \%)$ was significantly lower than xylazine $(n=$ $9 / 12,75 \% ; p=0.041)$, detomidine $(\mathrm{n}=10 / 12,83.3 \% ; p=0.013)$, medetomidine $(\mathrm{n}=9 / 12,75 \% ; p=0.041)$ and dexmedetomidine $(\mathrm{n}=10 / 12,83.3 \% ; p=0.013)$; but no significant differences were observed among different $a_{2}$-adrenergic agonists groups.

\section{Conclusion}

$\mathrm{Alph}_{2}$-adrenergic agonists are effective on increasing the pregnancy rate of SCNT embryo transfer in goats in this study. No significant differences were detected among different $\mathrm{a}_{2}$-adrenergic agonists.

\section{Background}

In addition to physical restraint, chemical agents are useful and often necessary to ensure immobility and to provide sedation and analgesia for surgical and non-surgical procedures in the veterinary patients [1, 2]. Many $\mathrm{a}_{2}$-adrenergic agonists and narcotics are commonly used for sedation, analgesia, and anesthesia in ruminants [3-5].

Embryo transfer is an important technique to improve pregnancy rate as well as provides an opportunity to utilize the genetic contribution. Laparoscopy is one of the most useful and non-invasive surgical 
techniques used in small ruminants for embryo transfer [1, 6, 7] and artificial insemination [8]. Even this less invasive technique is not without stress and/or risks that may result in decreased pregnancy rates and poorer reproductive performance [9]. The premise of this study is that using sedation via $a_{2^{-}}$ adrenergic agonists will improve outcomes.

Due to the significant effects of different $a_{2}$-adrenergic agonists on cortisol level and physiological variables $[10,11]$ and the lack of documented information on the effects of different $a_{2}$-adrenergic agonists on pregnancy rate during laparoscopic embryo transfer in small ruminants, The present study was conducted to determine if using $a_{2}$-adrenergic agonists results in decreased stress levels (lower cortisol levels) in goats used for laparoscopic embryo [somatic cell nuclear transfer (SCNT)] transfer; and there is an effect on pregnancy rate when stress levels are lessened. It is hypothesized that the effects of $\mathrm{a}_{2}$-adrenergic agonists during laparoscopic SCNT embryo transfer would affect the pregnancy rate after IV administration in goats.

\section{Results}

All animals finish the study, and the procedure was not repeated in any does. Half of the goats in each group were showed vocalization (in different patterns) during the procedures. Also, two animals in each group were showed some complications (such as regurgitate, salivate, aspirate and bloat) after the procedures. All goats had recovered by 3 hours base on behavioral signs such as standing, head up, head and ear movement, consciousness, and responsiveness. Physiological variables are indicated in Table 1. According to the results, HR and RR significantly increased from baseline 15-45 minutes after normal saline administration. In XYL, DET, MED, and DEX, HR significantly decreased from baseline 5-120 minutes after drug administration. HR was significantly lower in $a_{2}$-adrenergic agonists groups at 5-90 minutes after drug administration compared to the control. In $a_{2}$-adrenergic agonists groups, a significant decrease from baseline in RR was detected between 30-60 minutes after drug administration. RR was significantly lower in $\mathrm{a}_{2}$-adrenergic agonists groups at 15-60 minutes after drug administration compared to the control. Ruminal motility was decreased in $a_{2}$-adrenergic agonists groups at 5,90 , and 120 minutes and absent at 10-60. Compared to control, ruminal motility was significantly lower in $a_{2}-$ adrenergic agonists groups at 5-120 minutes after drug administration. There were no significant differences in $\mathrm{HR}, \mathrm{RR}$, and ruminal motility among different $\mathrm{a}_{2}$-adrenergic agonists groups at all time points. No significant differences were observed in RT at different times in each group or among groups. CRT (capillary refill time) was less than two seconds at all time points following each drug. 
Table 1

Comparing xylazine, detomidine, medetomidine on physiological variables (mean \pm standard deviation) during laparoscopic embryo (somatic cell nuclear transfer) transferring in 60 does. Animals were assigned to five intravenous groups: control (normal saline, $5 \mathrm{~mL}$ ); XYL, xylazine (100 g kg-1); DET, detomidine (50 g kg-1); MED, medetomidine (20 g kg-1); and DEX, dexmedetomidine $(5 \mathrm{~g} \mathrm{~kg}-1)$.

\begin{tabular}{|c|c|c|c|c|c|c|c|c|c|c|}
\hline \multirow[t]{2}{*}{ Varaibles } & \multirow[t]{2}{*}{ Groups } & \multicolumn{9}{|c|}{ Time (minutes) } \\
\hline & & Baseline & 5 & 10 & 15 & 30 & 45 & 60 & 90 & 120 \\
\hline \multirow[t]{5}{*}{$\begin{array}{l}\text { HR (beats } \\
\text { minute }^{-1} \text { ) }\end{array}$} & Control & $107 \pm 5$ & $\begin{array}{l}106 \\
\pm 5\end{array}$ & $\begin{array}{l}107 \\
\pm 3\end{array}$ & $\begin{array}{l}118 \\
\pm 4 \\
+\end{array}$ & $\begin{array}{l}118 \\
\pm 3 \\
+\end{array}$ & $\begin{array}{l}119 \\
\pm 3 \\
+\end{array}$ & $\begin{array}{l}107 \\
\pm 4\end{array}$ & $\begin{array}{l}108 \\
\pm 3\end{array}$ & $\begin{array}{l}106 \\
\pm 4\end{array}$ \\
\hline & $X Y L$ & $105 \pm 6$ & $\begin{array}{l}100 \\
\pm 6 \\
*+\end{array}$ & $\begin{array}{l}95 \pm \\
5^{*+}\end{array}$ & $\begin{array}{l}90 \pm \\
6^{*+}\end{array}$ & $\begin{array}{l}80 \pm \\
6^{*+}\end{array}$ & $\begin{array}{l}79 \pm \\
4^{*+}\end{array}$ & $\begin{array}{l}81 \pm \\
4^{\text {*+ }}\end{array}$ & $\begin{array}{l}87 \\
\pm 4 \\
\star\end{array}$ & $\begin{array}{l}106 \\
\pm 5\end{array}$ \\
\hline & DET & $108 \pm 3$ & $\begin{array}{l}100 \\
\pm 2 \\
*+\end{array}$ & $\begin{array}{l}97 \pm \\
3^{*+}\end{array}$ & $\begin{array}{l}94 \pm \\
4^{*+}\end{array}$ & $\begin{array}{l}84 \\
\pm 4 \\
*+\end{array}$ & $\begin{array}{l}82 \pm \\
4^{\star+}\end{array}$ & $\begin{array}{l}84 \pm \\
3^{*+}\end{array}$ & $\begin{array}{l}89 \\
\pm 2 \\
*+\end{array}$ & $\begin{array}{l}107 \\
\pm 3\end{array}$ \\
\hline & MED & $103 \pm 4$ & $\begin{array}{l}98 \pm \\
3^{\text {*t }}\end{array}$ & $\begin{array}{l}93 \pm \\
5^{*+}\end{array}$ & $\begin{array}{l}89 \pm \\
4^{\text {*t }}\end{array}$ & $\begin{array}{l}81 \\
\pm 3 \\
*+\end{array}$ & $\begin{array}{l}79 \pm \\
4^{\star+}\end{array}$ & $\begin{array}{l}82 \pm \\
3^{\text {*+ }}\end{array}$ & $\begin{array}{l}87 \\
\pm 3 \\
*+\end{array}$ & $\begin{array}{l}103 \\
\pm 3\end{array}$ \\
\hline & DEX & $107 \pm 6$ & $\begin{array}{l}100 \\
\pm 4 \\
\text { *中 }\end{array}$ & $\begin{array}{l}96 \pm \\
6^{*+}\end{array}$ & $\begin{array}{l}92 \pm \\
5^{\text {*t }}\end{array}$ & $\begin{array}{l}82 \\
\pm 5 \\
x_{+}\end{array}$ & $\begin{array}{l}83 \\
\pm 5 \\
*+\end{array}$ & $\begin{array}{l}83 \pm \\
4^{\text {*+ }}\end{array}$ & $\begin{array}{l}87 \\
\pm 4 \\
\star \\
*\end{array}$ & $\begin{array}{l}107 \\
\pm 6\end{array}$ \\
\hline \multirow{5}{*}{$\begin{array}{l}\text { RR } \\
\text { (breaths } \\
\text { minute }^{-1} \text { ) }\end{array}$} & Control & $29 \pm 2$ & $\begin{array}{l}28 \pm \\
2\end{array}$ & $\begin{array}{l}28 \pm \\
2\end{array}$ & $\begin{array}{l}32 \pm \\
1^{+}\end{array}$ & $\begin{array}{l}32 \pm \\
1^{+}\end{array}$ & $\begin{array}{l}32 \pm \\
1^{+}\end{array}$ & $\begin{array}{l}28 \pm \\
1\end{array}$ & $\begin{array}{l}28 \pm \\
1\end{array}$ & $\begin{array}{l}29 \pm \\
1\end{array}$ \\
\hline & $X Y L$ & $28 \pm 1$ & $\begin{array}{l}27 \pm \\
1\end{array}$ & $\begin{array}{l}27 \pm \\
1\end{array}$ & $\begin{array}{l}26 \pm \\
1^{\text {*t }}\end{array}$ & $\begin{array}{l}24 \pm \\
1^{*+}\end{array}$ & $\begin{array}{l}23 \pm \\
1^{*+}\end{array}$ & $\begin{array}{l}25 \pm \\
1^{*+}\end{array}$ & $\begin{array}{l}27 \pm \\
1\end{array}$ & $\begin{array}{l}28 \pm \\
1\end{array}$ \\
\hline & DET & $28 \pm 2$ & $\begin{array}{l}27 \pm \\
2\end{array}$ & $\begin{array}{l}27 \pm \\
2\end{array}$ & $\begin{array}{l}26 \pm \\
2^{*+}\end{array}$ & $\begin{array}{l}24 \pm \\
2^{*+}\end{array}$ & $\begin{array}{l}23 \pm \\
2^{*+}\end{array}$ & $\begin{array}{l}25 \pm \\
1^{\text {*t }}\end{array}$ & $\begin{array}{l}27 \pm \\
2\end{array}$ & $\begin{array}{l}28 \pm \\
2\end{array}$ \\
\hline & MED & $29 \pm 2$ & $28 \pm$ & $28 \pm$ & $\begin{array}{l}27 \pm \\
2^{*+}\end{array}$ & $\begin{array}{l}25 \pm \\
2^{\text {*t }}\end{array}$ & $\begin{array}{l}24 \pm \\
2^{*+}\end{array}$ & $\begin{array}{l}25 \pm \\
2^{\text {*t }}\end{array}$ & $\begin{array}{l}27 \pm \\
2\end{array}$ & $28 \pm$ \\
\hline & DEX & $29 \pm 2$ & $\begin{array}{l}28 \pm \\
2\end{array}$ & $28 \pm$ & $\begin{array}{l}27 \pm \\
2^{*+}\end{array}$ & $\begin{array}{l}24 \pm \\
2^{*+}\end{array}$ & $\begin{array}{l}24 \pm \\
2^{*+}\end{array}$ & $\begin{array}{l}25 \pm \\
2^{*+}\end{array}$ & $27 \pm$ & $\begin{array}{l}28 \pm \\
1\end{array}$ \\
\hline \multirow[t]{3}{*}{$\mathrm{RT}\left({ }^{\circ} \mathrm{C}\right)$} & Control & $\begin{array}{l}38.8 \pm \\
0.2\end{array}$ & $\begin{array}{l}38.8 \\
\pm \\
0.2\end{array}$ & $\begin{array}{l}38.8 \\
\pm \\
0.3\end{array}$ & $\begin{array}{l}38.9 \\
\pm \\
0.2\end{array}$ & $\begin{array}{l}38.6 \\
\pm \\
0.3\end{array}$ & $\begin{array}{l}38.6 \\
\pm \\
0.2\end{array}$ & $\begin{array}{l}38.6 \\
\pm \\
0.2\end{array}$ & $\begin{array}{l}38.7 \\
\pm \\
0.1\end{array}$ & $\begin{array}{l}38.6 \\
\pm \\
0.1\end{array}$ \\
\hline & $X Y L$ & $\begin{array}{l}38.7 \pm \\
0.4\end{array}$ & $\begin{array}{l}38.6 \\
\pm \\
0.1\end{array}$ & $\begin{array}{l}38.7 \\
\pm \\
0.2\end{array}$ & $\begin{array}{l}38.8 \\
\pm \\
0.2\end{array}$ & $\begin{array}{l}38.8 \\
\pm \\
0.2\end{array}$ & $\begin{array}{l}38.6 \\
\pm \\
0.2\end{array}$ & $\begin{array}{l}38.7 \\
\pm \\
0.2\end{array}$ & $\begin{array}{l}38.5 \\
\pm \\
0.2\end{array}$ & $\begin{array}{l}38.8 \\
\pm \\
0.2\end{array}$ \\
\hline & DET & $\begin{array}{l}38.6 \pm \\
0.3\end{array}$ & $\begin{array}{l}38.7 \\
\pm \\
0.2\end{array}$ & $\begin{array}{l}38.6 \\
\pm \\
0.2\end{array}$ & $\begin{array}{l}38.6 \\
\pm \\
0.2\end{array}$ & $\begin{array}{l}38.8 \\
\pm \\
0.2\end{array}$ & $\begin{array}{l}38.8 \\
\pm \\
0.3\end{array}$ & $\begin{array}{l}38.8 \\
\pm \\
0.3\end{array}$ & $\begin{array}{l}37.8 \\
\pm \\
0.3\end{array}$ & $\begin{array}{l}38.6 \\
\pm \\
0.2\end{array}$ \\
\hline
\end{tabular}




\begin{tabular}{|c|c|c|c|c|c|c|c|c|c|c|}
\hline & MED & $\begin{array}{l}38.8 \pm \\
0.1\end{array}$ & $\begin{array}{l}38.8 \\
\pm \\
0.1\end{array}$ & $\begin{array}{l}38.7 \\
\pm \\
0.2\end{array}$ & $\begin{array}{l}38.7 \\
\pm \\
0.2\end{array}$ & $\begin{array}{l}38.6 \\
\pm \\
0.2\end{array}$ & $\begin{array}{l}38.6 \\
\pm \\
0.2\end{array}$ & $\begin{array}{l}37.9 \\
\pm \\
0.3\end{array}$ & $\begin{array}{l}37.8 \\
\pm \\
0.3\end{array}$ & $\begin{array}{l}38.7 \\
\pm \\
0.2\end{array}$ \\
\hline & DEX & $\begin{array}{l}38.6 \pm \\
0.2\end{array}$ & $\begin{array}{l}38.7 \\
\pm \\
0.1\end{array}$ & $\begin{array}{l}38.6 \\
\pm \\
0.2\end{array}$ & $\begin{array}{l}38.7 \\
\pm \\
0.2\end{array}$ & $\begin{array}{l}38.7 \\
\pm \\
0.1\end{array}$ & $\begin{array}{l}38.7 \\
\pm \\
0.3\end{array}$ & $\begin{array}{l}37.7 \\
\pm \\
0.3\end{array}$ & $\begin{array}{l}38.7 \\
\pm \\
0.2\end{array}$ & $\begin{array}{l}38.6 \\
\pm \\
0.3\end{array}$ \\
\hline \multirow{5}{*}{$\begin{array}{l}\text { Ruminal motility } \\
\text { (contraction } \\
\text { minutes }^{-1} \text { ) }\end{array}$} & Control & 2 & 2 & 2 & 2 & 2 & 2 & 2 & 2 & 2 \\
\hline & $X Y L$ & 2 & $1^{*+}$ & $0^{*}$ & $0^{* \dagger}$ & $0^{*+}$ & $0^{*+}$ & $0^{*+}$ & $1^{\text {*十 }}$ & $1^{* \dagger}$ \\
\hline & DET & 2 & $1^{*+}$ & $0^{*+}$ & $0^{*}$ & $0^{*}$ & $0^{*+}$ & $0^{*+}$ & $1^{*+}$ & $1^{*+}$ \\
\hline & MED & 2 & $1^{\text {* }}$ & $0^{*+}$ & $0^{*}$ & $0^{*+}$ & $0^{*+}$ & $0^{*+}$ & $1^{\star \star}$ & $1^{*+}$ \\
\hline & DEX & 2 & $1^{\text {* }}$ & $0^{*+}$ & $0^{*}$ & $0^{*+}$ & $0^{*+}$ & $0^{*+}$ & $1^{*+}$ & $1^{*+}$ \\
\hline \multirow[t]{5}{*}{ Cortisol (nmol/l) } & Control & $59 \pm 11$ & - & - & - & - & $\begin{array}{l}80 \pm \\
8^{+}\end{array}$ & - & - & $\begin{array}{l}61 \pm \\
14\end{array}$ \\
\hline & $X Y L$ & $60 \pm 13$ & - & - & - & - & $\begin{array}{l}34 \pm \\
6^{*+}\end{array}$ & - & - & $48 \pm$ \\
\hline & DET & $63 \pm 12$ & - & - & - & - & $\begin{array}{l}34 \pm \\
7^{*+}\end{array}$ & - & - & $\begin{array}{l}45 \pm \\
3^{*+}\end{array}$ \\
\hline & MED & $60 \pm 13$ & - & - & - & - & $\begin{array}{l}36 \pm \\
4^{\star+}\end{array}$ & - & - & $\begin{array}{l}46 \pm \\
5^{*+}\end{array}$ \\
\hline & DEX & $63 \pm 11$ & - & - & - & - & $\begin{array}{l}35 \pm \\
5^{*+}\end{array}$ & - & & $\begin{array}{l}44 \pm \\
3^{*+}\end{array}$ \\
\hline \multicolumn{11}{|c|}{$H R$, heart rate; RR, respiratory rate; $R T$, rectal temperature. } \\
\hline \multicolumn{11}{|c|}{ *Significantly different from control at the same time point $(p<0.05)$} \\
\hline
\end{tabular}

Serum cortisol values significantly increased from baseline in the control group 45 minutes after drug administration $(p=0.001)$. At T45 and T120, serum cortisol concentration was significantly lower in $\mathrm{a}_{2}$ adrenergic agonists groups compared with control; however, no significant differences were observed among different $a_{2}$-adrenergic agonists (Table 1 ). serum cortisol concentration decreased from baseline in $\mathrm{a}_{2}$-adrenergic agonists groups 45 and 120 minutes after drug administration.

The pregnancy rate in control group $(\mathrm{n}=4 / 12,33.3 \%)$ was significantly lower than XYL $(\mathrm{n}=9 / 12,75 \% ; p$ $=0.041), \operatorname{DET}(n=10 / 12,83.3 \% ; p=0.013), \operatorname{MED}(n=9 / 12,75 \% ; p=0.041)$ and $\operatorname{DEX}(n=10 / 12,83.3 \% ; p$ 
$=0.013)$; but no significant differences were observed among different $a_{2}$-adrenergic agonists groups. The animals were not pregnant were not used again.

\section{Discussion}

$a_{2}$-adrenergic agonists are widely used in sedation, analgesia, and restraint of small ruminants. These drugs bind to $a_{2}$-agonist receptors in the brain and spinal cord [5]. $a_{2}$-agonist' doses used in the present study were determined based on the doses of these drugs used in other studies in small ruminants [1315]. Nowadays, the laparoscopy technique is widely used in many veterinary procedures (e.g., embryo transfer) $[6,8]$. Reducing stress levels in animals during veterinary interventions such as laparoscopy was emphasized $[9,16]$.

The goats in each group were showed some side effects (such as vocalization, regurgitation, salivation, aspiration, and bloat) during this study. Recumbency in a sedated ruminant is potentially dangerous since they can regurgitate and possibly aspirate this fluid [17, 18]. De Carvalho et al. (2016) demonstrated that IV administration of xylazine in sheep leads to drooling and urination [4]. Sheep exhibited clinical signs of mydriasis, urination, drooling, and vocalization after IV administration of dexmedetomidine IV [3]. Alph ${ }_{2}$-adrenergic agonists greatly affect oxygenation also [3]. With the positioning used in this study and using the insufflations of abdomen for laparoscopy, these animals are very likely to suffer hypoxemia. Therefore, the animals in this study were given oxygen to try to avoid any hypoxemia.

HR and RR significantly increased from baseline at 15-45 minutes, and cortisol significantly increased from baseline at 45 minutes in the control group. The incidence of laparoscopy-related stress and physiological changes during artificial insemination [8] and embryo transfer $[1,12,16]$ was reported in ruminants. Stress and physiological changes can reduce pregnancy rate and productivity in husbandry units $[6,9,16]$.

Different $a_{2}$-adrenergic agonists a significant reduction in RR between 30 and 60 minutes after drug administration. Furthermore, these drugs a significant reduction in HR 5 to 90 minutes and ruminal motility 5 to 120 minutes after drug administration. In my country, xylazine is readily available and very inexpensive, while detomidine and dexmedetomidine are much more expensive. Medetomidine is not readily available anymore. The decrease in physiological variables (HR, RR, and ruminal motility) following $\mathrm{a}_{2}$-adrenergic agonists were reported in other small ruminants such as sheep and goats $[17,18]$ and camels [2]. By affecting the hormonal and nervous systems, $a_{2}$-adrenergic agonists reduce HR, RR, and gastrointestinal motility $[5,10,19]$. The serum cortisol levels were significantly lower in different $a_{2}{ }^{-}$ adrenergic agonists groups than in normal saline. Reduction in the concentration of serum cortisol level following $a_{2}$-adrenergic agonists has been reported in previous studies with another stress such as surgery or restraint or even isolation from other animals $[9,10]$.

The pregnancy rate of embryos (SCNT) transferred was significantly higher in different $\mathrm{a}_{2}$-adrenergic agonists groups than in normal saline. The use of sedatives during laparoscopic examination in sheep [9] 
and laparoscopic embryo transfer in sheep and goats [12] was recommended. The pregnancy rate of SCNT embryos in Baguisi et al. (1999)' study was lower than this study. It may be due to the sedative drugs in this study [20]. It should be noted that the SCNT embryos are valuable and expensive, so it is important to achieve a good pregnancy rate with fewer of them. Two embryos were transferred into uterine horns of recipient goats that were lesser than other uterine horns [21] or tubal [22] embryo transfer. Fonseca et al. (2016) suggested that the improved technique, better animal welfare, and shorter surgery time could be helpful for embryo transfer [12]. There are articles using other procedures (electroejaculator, rumenotomy, etc.) that suggest the use of anesthetics/sedatives improves the outcome they are looking for [19]. Good restraint is important to getting a producer done efficiently and correctly. Actual immobility and lack of response to surgery by the patient likely helps the surgeon perform the embryo transfer properly and more quickly. Most all surgeons can do a better job when the animal is not moving, struggling, and/or vocalizing [14].

The examined animals were laid upside down from 5 to 45 minutes after drug administration; therefore, the assessed duration and quality of sedation might be erroneous. More frequent measurement of cortisol to see if it is increased during surgery or was low throught, would have been very useful.

\section{Conclusion}

$\mathrm{Alph}_{2}$-adrenergic agonists are effective on increasing the pregnancy rate of embryo (SCNT) transfer in goats in this study. No significant differences were detected among xylazine (at $100 \mu \mathrm{g} \mathrm{kg}^{-1}$ ), detomidine (at $50 \mu \mathrm{g} \mathrm{kg}^{-1}$ ), medetomidine (at $20 \mu \mathrm{g} \mathrm{kg}^{-1}$ ) and dexmedetomidine (at $5 \mu \mathrm{g} \mathrm{kg}^{-1}$ ). More investigations with more frequent evaluation of cortisol and longer periods of monitoring (at least until parturition) are recommended.

\section{Methods}

\section{Animals}

The study was confirmed by the animal welfare commission of the Faculty of Veterinary Medicine, Shahid Bahonar University of Kerman (no. IR.UK.VETMED.REC.1399.009). Sixty healthy does aged $24 \pm 4$ months and weighing $30 \pm 3 \mathrm{~kg}$ [mean \pm standard deviation (SD)] were used. The animals were selected from the Animal Husbandry Unit of Royan Institute for Biotechnology, Isfahan (latitude $32^{\circ} 67^{\prime} \mathrm{N}$ and longitude $\left.51^{\circ} 77^{\prime} \mathrm{E}\right)$, Iran using a sample lottery method (simple randomization). All animals were housed under the same husbandry, nutritional, and management conditions in the same group pen. The animals received a constant mixture containing roughages (mainly alfalfa hay and wheat straw) and concentrate (barley grain, soybean meal, wheat bran) base on physiological maintenance during the experiment. The forage/concentrate ratios during the experiment were 90:10. Minerals and vitamins were also added to the rations. Two months before the experiment, animals were treated with broad-spectrum antiparasitic drugs for probable internal and external parasitic infestation. The health status of all animals was checked routinely by clinical (including heart and respiratory rate, rectal temperature, capillary refill time, 
and ruminal motility) and paraclinical examinations. The paraclinical examination consisted of hematological (evaluation of complete blood count and packed cell volume) and fecal parasitic analysis. The does had no history of reproductive problems, and they were bred successfully in the past. Any of does didn't have difficulty becoming pregnant.

The study was performed during the breeding season. Before the experiment, food and water were withheld from the goats for 12 and 6 hours, respectively. The experiment was carried out in the morning. The animals were weighed for the calculation of drug dosages. One animal was studied at any one time. The animals were unable to see or interact with each other. The skin over the left jugular vein was prepared aseptically for IV administration and blood sampling. Animals rested for 20 minutes before drug administration (baseline).

\section{Experimental procedures}

Animals were assigned randomly to five IV groups: control (normal saline, $5 \mathrm{~mL}) ; \mathrm{XYL}$, xylazine $(100 \mu \mathrm{g}$ $\mathrm{kg}^{-1}$; Xyla, $2 \%$; Interchemie Werken De Adelaar B.V., Netherlands); DET, detomidine (50 $\mathrm{g} \mathrm{kg}^{-1}$; Domosedan, Orion Corporation, Finland); MED, medetomidine (20 $\mathrm{g} \mathrm{kg}^{-1}$; DorbeneVet; N-Vet AB, Sweden); and DEX, dexmedetomidine ( $5 \mathrm{\mu g} \mathrm{kg}^{-1}$; Dexdomitor; Orion Corporation, Finland). The injection volumes of treatments were the same for each animal by dilution with normal saline to $5 \mathrm{~mL}$. Drugs were administered IV in the left jugular vein (over 20 seconds) via an 18 gauge needle with the animals standing. Animals were placed on the special cradle 5 minutes after the treatment (Figure 1). The embryos were produced via SCNT technique, according to Hajian et al. (2020)'s study in Royan Institute for Biotechnology, Isfahan, Iran [7]. Recipient goats were synchronized using a vaginal progesterone device (Eazi-Breed CIDR, Zoetis, Australia) for 7 days. Then, equine chorionic gonadotropin (eCG) hormone (GONASER®, HIPRA, Spain) 400 IU on day 5, cloprostenol sodium (estroPLAN; Parnell Technologies, Australia) $250 \mu \mathrm{g}$ on day 7, and human chorionic gonadotrophin (hCG) hormone (Choragon, Ferring, Germany) 1000 IU on day 9 were administered. On day 16, 7-day embryos were transferred by laparoscopic methods recipients. The animals were gently restrained for laparoscopy embryo transfer and placed on the special $45^{\circ}$ cradle on top of a soft mattress for 10 minutes. The animals laid in dorsal recumbency position with their head down in lateral on the left side, and their legs were tied. The heads were positioned so the saliva and any reflux from the gastrointestinal tract would drain away from the throat. Animals were given oxygen. The skin over the areas for the laparoscopic port (on the ventral side of the abdomen) was prepared aseptically. Local anesthetic was performed by lidocaine $\left(0.22 \mathrm{mg} \mathrm{kg}^{-1}\right.$; Lidocaine $0.2 \%$, Pasture Institute, Iran). After disinfecting the surgical area, a 10$\mathrm{mm}$ trocar was used to pass telescope $0^{\circ}$ (Hopkins II, Karl Storz, Germany) into the abdominal cavity, about $6-\mathrm{cm}$ cranial to the teats and $3-\mathrm{cm}$ from the midline right side away from the rumen. Ovaries were examined to detect the corpus luteum. Embryo transfer began at 15 minutes and continued till 45 minutes post-treatment. Two embryos were inserted into the equivalent uterine horn to the ovary with an active corpus luteum using a handmade pipette $[1,7,12]$. At 45 minutes point, animal legs were untied, and they were gently placed on the floor (with soft mattress) in sternal position and allowed to recover. The animals were positioned to try to avoid any complications such as regurgitation, aspiration, and 
bloat. The animals were monitored in recovery every 15 minutes after the procedure. All investigators recording measurements were blinded to the treatment assigned.

\section{Physiological variables}

Physiological variables including heart rate (HR), respiratory rate (RR), rectal temperature (RT), capillary refill time (CRT), and ruminal motility were recorded at baseline (before drug administration) and 5, 10, 15, $30,45,60,90$, and 120 minutes after drug administration. HR and RR were assessed using a veterinary stethoscope (Classic SE Littmann; 3M, MN, USA) on the left 4th and 6th intercostal space for 1 minute. Ruminal motility was recorded by auscultation with a stethoscope placed on the left flank. The number of audible rumen contractions within 2 minutes was counted. CRT was measured by finger pressing on the labial surface of the gingiva in the incisor region. A digital thermometer (FT09; Beurer GmbH, Germany) was used to performed RT. The thermometer was 4-5 cm deep in touch with rectal mucosa for at least 2 minutes. Serum cortisol concentration was investigated via the radioimmunoassay method (Orion Diagnostica, Finland) at baseline, 45 and 120 minutes after drug administration. 45 minutes sample was at the end of the laparoscopy, and the goats were still restrained in the cradle. The pregnancy detection in animals was performed by transabdominal B-mode ultrasonography (Imago, ECM, France) 38 days after embryo transfer. The pregnancy rate was calculated using the following formula: Pregnancy rate = (animals pregnant/animals which had embryos transferred) × 100 .

\section{Statistical analysis}

Physiological variables (HR, RR, RT, CRT, and ruminal motility) were expressed as mean \pm standard deviation (SD). All statistical analysis was performed using SPSS 23.0 (SPSS for Windows, SPSS Inc, Chicago, Illinois). Kolmogorov-Smirnov test was used for testing data normality. Two-way repeatedmeasures analysis of variance (ANOVA) with Tukey's post hoc test was used to compare mean values of physiological variables. The paired sample $t$-test was applied to compare physiological variables at different times from baseline in each group. A chi-square test was performed to compare the rates of pregnancy among different groups. Differences were considered statistically significant when the calculated $p$-value was less than 0.05 .

\section{Abbreviations}

SCNT: Somatic cell nuclear transfer; HR: Heart rate; RR: Respiratory rate; RT: Rectal temperature; IV: Intravenous; CRT: Capillary refill time; XYL: Xylazine; DET: Detomidine; MED: Medetomidine; DEX: Dexmedetomidine; eCG: Equine chorionic gonadotrophin; SD: Standard deviation.

\section{Declarations}

\section{Acknowledgements}

The authors thank the Royan Institute for Biotechnology and its farm workers for their cooperation during sampling of this study. 


\section{Authors' contributions}

ASS: Study concept and design, project implementation, data acquisition and sorting, analysis of reports, statistical analysis, technical support, manuscript authorship. SMA: Corresponding author, Project implementation, study concept and design, technical support, restraint of animals, manuscript authorship. MH: Study concept and design, Project implementation, study concept and design, data acquisition and sorting, technical support. AMS: Analysis of reports, statistical analysis, technical support, manuscript authorship. AO: Project implementation, study concept and design, Technical support, restraint of animals, study concept and design, data acquisition and sorting. All authors approved the final version of this manuscript.

\section{Funding}

Not applicable.

\section{Availability of data and materials}

All data generated or analyzed during this study are available from the corresponding authors on reasonable request.

\section{Ethics approval and consent to participate}

All ethical considerations including utilizing animals were considered cautiously. The trial convention was affirmed by the animal welfare committee (which was covered IACUC approval) of the Faculty of Veterinary Medicine, Shahid Bahonar University of Kerman, Kerman, Iran (institutional approval number IR.UK.VETMED.REC.1399.009). All applicable international, national, and/or institutional guidelines for the care and use of animals were followed.

\section{Consent for publication}

Not applicable.

\section{Competing interests}

The authors declare that they have no competing interests.

\section{References}

1. Ishwar A, Memon M. Embryo transfer in sheep and goats: a review. Small Rumin Res. 1996;19(1):35-43.

2. Samimi AS, Sakhaee E, Iranmanesh F. Evaluation of sedative, analgesic, physiological, and laboratory effects of two doses off medetomidine and xylazine in dromedary calves. J Vet Pharmacol Ther. 2019;42(4):411-19. 
3. Borges LP, Nishimura LT, Carvalho LL, Cerejo SA, Auckburally A, Mattos-Junior E. Behavioral and cardiopulmonary effects of dexmedetomidine alone and in combination with butorphanol, methadone, morphine or tramadol in conscious sheep. Vet Anaesth Analg. 2016;43(5):549-60.

4. de Carvalho LL, Nishimura LT, Borges LP, Cerejo SA, Villela IO, Auckburally A, de Mattos-Junior E. Sedative and cardiopulmonary effects of xylazine alone or in combination with methadone, morphine or tramadol in sheep. Vet Anaesth Analg. 2016;43(2):179-88.

5. Kästner SB. A2-agonists in sheep: a review. Vet Anaesth Analg. 2006;33(2):79-96.

6. Haan J, Hay Kraus BL, Sathe SR. A comparison of the effects of carbon dioxide and medical air for abdominal insufflation on respiratory parameters in xylazine-sedated sheep undergoing laparoscopic artificial insemination. N Z Vet J. 2018;66(4):167-71.

7. Hajian M, Jafarpour F, Aghamiri SM, Varnosfaderani SR, Esfahani MHN. Effects of ovary storage temperature and embryo vitrification on somatic cell nuclear transfer outcomes in goats. Reprod Fertil Dev. 2020;32(4):419-24.

8. Aké-Villanueva JR, Aké-López JR, Segura-Correa JC, Magaña-Monforte JG, Aké-Villanueva NY. Factors affecting conception rate of hair ewes after laparoscopic insemination with chilled semen under tropical conditions. Small Rumin Res. 2017;153:114-17.

9. Stafford K, Chambers J, Sylvester S, Kenyon P, Morris S, Lizarraga I, de Nicolo G. Stress caused by laparoscopy in sheep and its alleviation. N Z Vet J. 2006;54(3):109-13.

10. Carroll GL, Hartsfield SM, Champney TH, Geller SC, Martinez EA, Haley EL. Effect of medetomidine and its antagonism with atipamezole on stress-related hormones, metabolites, physiologic responses, sedation, and mechanical threshold in goats. Vet Anaesth Analg. 2005;32(3):147-57.

11. Ranheim B, Horsberg T, Søli N, Ryeng K, Arnemo J. The effects of medetomidine and its reversal with atipamezole on plasma glucose, cortisol and noradrenaline in cattle and sheep. J Vet Pharmacol Ther. 2000;23(6):379-87.

12. Fonseca JF, Souza-Fabjan JMG, Oliveira MEF, Leite CR, Nascimento-Penido PMP, Brandão FZ, Lehloenya KC. Nonsurgical embryo recovery and transfer in sheep and goats. Theriogenology. 2016;86(1):144-51.

13. Moolchand M, Kachiwal A, Soomro S, Bhutto Z: Comparison of sedative and analgesic effects of xylazine, detomidine, and medetomidine in sheep. Egypt J Sheep Goats Sci. 2014;9(2):1-6.

14. Seddighi R, Doherty TJ. Field sedation and anesthesia of ruminants. Vet Clin N Am- Food Anim. 2016;32(3):553-70.

15. Shah Z, Kalhore A, Kachiwal A, Ahmad I, Sattar H, Khan M, Rehman Z, Khan F, Hussain T, Ullah H. Comparative studies on sedative and analgesic effects of xylazine and detomidine in goats. J Anim Plant Sci. 2013;23:39-42.

16. Purcell S, Beal W, Gray K. Effect of a CIDR insert and flunixin meglumine, administered at the time of embryo transfer, on pregnancy rate and resynchronization of estrus in beef cattle. Theriogenology. 2005;64(4):867-78. 
17. Celly C, McDonell W, Young S, Black W. The comparative hypoxaemic effect of four a2 adrenoceptor agonists (xylazine, romifidine, detomidine and medetomidine) in sheep. J Vet Pharmacol Ther. 1997;20(6):464-71.

18. Kutter AP, Kästner SBR, Bettschart-Wolfensberger R, Huhtinen M. Cardiopulmonary effects of dexmedetomidine in goats and sheep anaesthetised with sevoflurane. Vet Rec. 2006;159(19):624-9.

19. Abril-Sánchez S, Crosignani N, Freitas-de-Melo A, Terrazas A, Damián J, Beracochea F, Silveira P, Ungerfeld R. Sedation or anaesthesia decrease the stress response to electroejaculation and improve the quality of the collected semen in goat bucks. Animal. 2018;12(12):2598-608.

20. Baguisi A, Behboodi E, Melican DT, Pollock JS, Destrempes MM, Cammuso C, Williams JL, Nims SD, Porter CA, Midura P. Production of goats by somatic cell nuclear transfer. Nat Biotechnol. 1999;17(5):456-61.

21. Dovenski T, Trojacanec P, Petkov V, Popovska-Percinic F, Kochoski L, Grizelj J. Laparoscopypromising tool for improvement of reproductive efficiency of small ruminants. Maced Vet Rev. 2012;35(1):5-11.

22. Shin ST, Jang SK, Yang HS, Lee OK, Shim YH, Choi WI, Lee DS, Lee GS, Cho JK, Lee YW. Laparoscopy vs. laparotomy for embryo transfer to produce transgenic goats (Capra hircus). J Vet Sci. 2008;9(1):103-7.

\section{Figures}

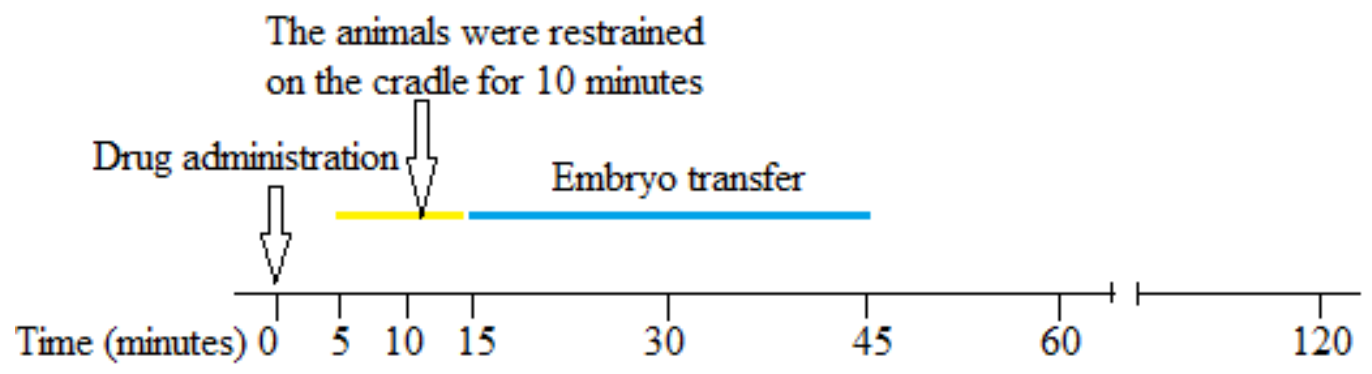

\section{Figure 1}

Schematic diagram of present experimental design. Animals rested for 20 minutes before drug administration (baseline). Drugs were administered intravenously in the left jugular vein with the animals standing. Animals were placed on the special cradle 5 minutes after the treatment. The animals were gently restrained for laparoscopy and placed on the special $45^{\circ}$ cradle on top of a soft mattress for 10 minutes. Embryo transfer began at 15 minutes and continued till 45 minutes post-treatment. The detection of pregnancy in animals was performed by transabdominal B-mode ultrasonography 38 days after embryo transfer. 